\title{
Theoretical and Practical Aspects of Economic Security of the Russian Forest Industry
}

\author{
Submitted 19/01/19, 1st revision 15/02/19, 2nd revision 10/04/19, accepted 26/05/19
}

\author{
M.A. Bulgakova ${ }^{1}$
}

\begin{abstract}
:
Purpose: The forest sector in Russia is of great ecological, economic and social importance not only locally, but also globally. Digitalization of society, of course, entails a change in financial, economic and legal postulates. The article indicates the interconnection between the economic security of the Russian Federation and security of forest industry.

Design / Methodology / Approach: The article reveals the prospects of economic security of forest industry on the basis of the analysis of statistical data on crimes committed and the historical background of Russian forest industry.

Results: On the basis of the conducted research the author gives recommendations on choosing the strategy for development of forestry in Russia, represents statistical data on crimes committed in forest industry.

Practical implications: The applied value of the study is expressed in highlighting the ways of Russian forest industry development as a vital element of Russian economy and economic security in the context of modern development of society.

Originality/Value: The originality of the author's approach is in summarizing the findings on the basis of regional, historical and legal analysis taking into account the transformation of economic systems and the modernization of the world community.
\end{abstract}

Keywords: National security, digitalization of society, economic security, forest industry.

JEL Codes: B16, B41, L73.

Paper Type: Research article in Special Issue dedicated to Russian Economy.

Section 8: Business and Economic Issues.

${ }^{1}$ Ph.D. in Economics, Senior Lecturer of the Department of Financial, Economic, Material, Technical and Medical Support, Academy of Management of the Ministry of Internal Affairs of Russia, Moscow, mbulgackova@yandex.ru 


\section{Introduction}

One of the most important human needs from the moment of birth and throughout life is the need for security. This need for a hierarchy of needs, developed by the American psychologist and founder of humanistic psychology A. Maslow, is at the base of the "pyramid" after physiological (quenching thirst, hunger). Even though the theory of motivation was developed for psychologists, it has found wide application in the economy, taking an important place in the construction of the rationale for consumer behavior and its needs for safe products. Developed after the death of the scientist (Maslow, 2014), the visual shell of the hierarchy of needs in the form of a pyramid is widely used by marketers and economists around the world.

It is generally accepted that the guarantor of stability and security, as an individual and society, is the state. However, it is impossible to ensure security without a sustainable economy, which depends on many factors, including long-term state policy, demand and level of competition, marketing, available human and natural resources, as well as a high degree of protection against various threats of internal and external nature. It should be noted that among the most important conditions for the progressive development, stability and correctness of the chosen course of foreign and domestic policy that characterize the country's sovereignty is national security and its economic security. One inhabitant of the Russian Federation accounts for more than $600 \mathrm{~m} 3$ of wood per root, which is much more than in any other country in the world. Forest resources of several regions of Russia, as well as the untouched territories preserved in them, have not only local, but also global importance in issues related to the global carbon and oxygen cycle. One of the serious problems of economic security of the forest sector in Russia is illegal logging, which is concentrated in areas with particularly valuable species, as well as located near markets and transport routes. In some regions profitability illegal logging business reaches $300 \%$. Illegal logging of forest plantations is not a new type of criminal attack, but the increase in their number indicates that this phenomenon has not received enough attention in the modern theory of economic security of economic sectors.

\section{Materials and Methods}

Before analyzing the features of the economic security of the forest sector, it is necessary to turn to the main methods and stages of the study of economic security, as any research, scientific or practical activity is carried out based on the use of methods, techniques and methodologies. There is no doubt that the problems associated with the definition of understanding and content of methodology and methodological tools are inherent in various areas of research, including economic security. In our opinion, the theory of economic security, in General, and a certain sphere is difficult to attribute to the formed theoretical systems. It is obvious that the field of study of the theory of economic security of the industry and the theory of the economy of the region, enterprises, States intersect, as they are based on the postulates about the structure and relationship of the elements of socio-economic systems, 
maintaining the stability of systems under the specified parameters, as well as countering the threats of negative consequences.

However, not only the relative "youth" of economic security as a scientific direction, led to the development of methodological research. For several reasons, the Russian Federation is now a developing market economy. At the same time, the state retained the most important function for the development of competition (Maksimov, 2018). In our opinion, domestic scientists and manufacturers soon need to develop and master (respectively) new principles of management of industries and enterprises. Otherwise, taking into account the increasing speed of the economy movement along the "rails" of the market model of the economic mechanism, coupled with the globalization and digitalization of society, the lack of knowledge and skills in the application of the principles and methods of marketing, the interaction of socioeconomic and environmental systems, the use of opportunities of electronic trading platforms and cryptocurrencies will entail an inevitable and significant slowdown in progress with the subsequent cessation of activities of all domestic industries.

Thus, one of the most important stages of the study of economic security is empirical system analysis, which is a kind of system analysis and represents perception through the senses. The empirical level of scientific knowledge can be characterized as a direct scientific study of real and sensually perceived objects.

Considering the fact that in each historical period the same social and economic phenomena have certain specific features, size, structure, as well as the intensity of development and prevalence, the author used statistical data. In this regard, and in order to measure the mass socio-economic phenomena, the quantitative side of threats and risks in inextricable connection with their qualitative content in relation to specific conditions of place and time, the method of statistical analysis was used, as well as a specific method of digital coverage of the phenomenon, acting on the basis of the principle of the dialectical method of knowledge.

\section{Discussion}

The category "national economic security" was first used in the message of the 32nd President of the United States of America Franklin Delano Roosevelt (Kornilov, 2009). At the same time, the definition of "economic security" in the United States is still missing. Experts from the leading American Research Corporation, RAND, proposed in 1994 to characterize national economic security as "the ability to protect or strengthen U.S. economic interests in relation to events, processes, or actions that may threaten or impede those interests, with threats that may be of foreign or domestic origin, intentional or unintentional, the consequences of human or natural activities" (Neu, 1994).

Not only foreign, but also Russian scientists are engaged in the study of economic security problems. The concept of "economic security" in Russia was originally con- 
sidered as "ensuring the conditions for the preservation of trade secrets and other confidential information of the enterprise" (Alekseenko, 1992; Belov, 1993). Even though the term "economic security" by historical standards of economic science is relatively young, it has firmly established itself and received wide coverage by domestic scientists and economists. Thus, 15 years ago, in 2003, researchers (Prokhozhev, 2003) in the Russian scientific literature counted about 30 definitions of "economic security", fundamentally different, but not refuting, but complementing each other. However, a single approach to its understanding has not yet been developed.

Thus, the concept of economic security is treated as the state of the economy and institutions of power, in which is provided the guaranteed protection of national interests, social orientation of its policies, sufficient defense capabilities even in unfavorable conditions for the development of internal and external processes that, in his opinion, means "not only the security of national interests, but also the willingness, the ability of government institutions to create mechanisms of implementation and protection of national interests in the development of the domestic economy, maintenance of social and political stability of society" (Senchagov, 1995).

The author agrees with the position that "economic security means reliable and provided with all the necessary means and institutions of the state (including law enforcement agencies and special services) protection of national and state interests in the economy from internal and external threats, economic and direct material damage" (Gorodetsky, 1995).

The relative novelty and lack of elaboration of the term "economic security" entails its unpopularity in the scientific literature of Western European States. At the same time, since the mid-80-ies of the last century due to the end of the "cold war", the expert group on the instructions of the UN Secretary-General carried out the development of the concept of security, which resulted in the conclusion of a comprehensive understanding of "security" in the military-political sense.

Analysis of the definitions of "national economic security" formulated by scientists from the United States, Japan, France, Canada, Spain, Greece, Hungary, Poland, Lithuania, Russia, shows that each group of countries is characterized by national characteristics and the use of different approaches (Kolupaev, 2002). Thus, for postSoviet States, "national economic security" is interpreted from the perspective of various interests (state, society, personality, industry). In post-socialist States through the prism of "international" security; in developed countries, sustainability is the main indicator of safety.

Therefore, among the main approaches to the definition of "economic security", we can distinguish "interests", "sustainability" and "independence". Professor of the Geneva Institute of international studies K. Gasteiger argues that the formation of the concept of "security" in a particular state has a significant impact on the histori- 
cal memory, geographical location and national perception of the outside world, as well as "pluralism in interpretation due to the lack of a single methodological framework, subjectivity in the assessments, the specifics of the tasks" (Kolupaev, 2002).

According to the current us "national security Strategy" among the main goals of American foreign and domestic policy are: strengthening military security, economic prosperity, promoting democracy in other countries (Lomovtseva, 2015). That is, the basis of economic security in the United States is economic stability, protected from losses and provided with favorable prospects for development.

Economic security, being a complex socio-economic condition, reflecting a significant number of changing under the influence of external and internal factors of circumstances, includes: the economic independence of the state; high standard of living of the population; the formation and preservation of productive forces that guarantee the increase in production while minimizing costs, with the possibility of recovery and sustainable use of resources; effective state management of the economy. The objects of economic security is the economic system and its constituent natural resources, real estate, production and non-production funds, financial resources, economic structures, society, family, personality. Processes and phenomena that negatively affect the economy and economy of the state, infringing on the interests of the individual and society as a whole, are usually characterized as threats to economic security.

However, according to some scientists (Kolupaev, 2002), the concept of "security" is artificially applied to all sectors and spheres of the economy in crisis. Thus, in foreign and Russian science there is no common understanding of economic security. The difference between the interpretation of "economic security" in foreign countries and the accepted characteristic of the term in Russia is that among the most important elements, foreign experts note the state of protection of national economies from external threats, including:

- security of supply of the most important resources;

- security of commercial information;

- stability and competitiveness in world markets.

In addition, it is widely believed in the Western scientific literature that economic security is the ability of the national economy to survive the global economic crises. At the same time, the understanding of "economic security" in China is similar to the Russian interpretation and is to maintain "economic sovereignty", independence of decision-making, as well as import substitution, military and political stability.

In the Strategy of national security of the Russian Federation, national security is interpreted as a state of protection of the individual, society and the state from internal and external threats, which ensures the implementation of the constitutional 
rights and freedoms of citizens of the Russian Federation, decent quality and standard of living, sovereignty, independence, state and territorial integrity, sustainable socio-economic development of the Russian Federation. In addition, the national security includes state, information, public, economic, energy, environmental security, as well as personal security. The threats to national security include a set of conditions and factors that create the possibility of harming national interests directly or indirectly, while the national interests of Russia are defined as "...objectively significant needs of the individual, society and the state in ensuring their security and sustainable development."

In our opinion, and taking into account the above, the economic security of Russia should be understood as ensuring economic sovereignty and sustainability of the national economy to external and internal challenges and threats, strengthening social and political stability through the solution of the main tasks for the implementation of the strategy, taking into account the digitalization of society and the greening of all industries.

"National interests" of the Russian Federation in the economic sphere are defined in the Strategy as "... objectively significant economic needs of the country, the satisfaction of which ensures the implementation of the strategic national priorities of the Russian Federation...".

Russia's forest resources are represented by large areas, and the volume is almost a quarter of the world's reserves. However, to talk about the economic efficiency of their use is currently not quite true. In earlier works, the author (Bulgakova, 2013) proposed to characterize the economic security of the forest-industrial complex as one of the conditions for sustainable development and sovereign functioning of the state, which is a state of regularity of the forest industry, where the probability of negative consequences for economic entities is minimized by mutually directed actions of state and non-state institutions in the economic sphere.

The forest sector of the Russian Federation with its huge resource reserves takes a very modest position in the economy of Russian, that, in our opinion, is due to the number of systemic problems, including: insufficient development of capacities for deep chemical, energy, mechanical processing of wood and low level of efficiency of the use of wood raw materials in the complex.

Taking into account the national security in our country as a system, the economic security of the forest industry in Russia is not only the current state of natural resources, production, financial potential of the industry, but also the development, implementation of a set of measures aimed at continuous development, together making up a mechanism to counter internal and external threats.

Thus, the economic security of the forest industry, taking into consideration forests and wood as the national interests of Russia, should be investigated in relation to 
four types of security, such as environmental, informational (digital), social, food ones (Figure 1).

In the Russian Federation, natural resources are used and protected by the state as the basis for life and activity of the people. Every citizen of our country has the right to a favorable environment, reliable information about its condition and compensation for damage caused to health or property by environmental law. The forests of Russia, being the main supplier of oxygen on the planet, have a significant impact on the balance of the process of maintaining the stability of the environment, regulating the water regime of rivers and reservoirs, mitigating the impact of droughts and dry lands, as well as protecting the soil from water and wind erosion.

The forests of Russia, being the main supplier of oxygen on the planet, have a significant impact on the balance of the process of maintaining the stability of the environment, regulating the water regime of rivers and reservoirs, mitigating the impact of droughts and dry lands, as well as protecting the soil from water and wind erosion. Forests are located on the lands of the forest fund, which consists of forest lands (lands covered with forest vegetation and not covered with it but intended for its restoration. - cutting, burning, thinned forest, glades and others) and intended for forestry non-forest land (glades, roads, swamps and others). The forest Fund belongs to the Federal state property, while it can transfer a part of the forest fund to the ownership of the subjects of the Russian Federation. Trees and shrubs that have appeared as a result of human activity or in a natural way on a land after its transfer to a citizen or legal entity are the property of a person or organization. Thus, in addition to the ownership of such trees and shrubs, there are extended rights to own, use and dispose them at will.

Figure 1. Place of economic security of the forest industry in the national security system of Russia

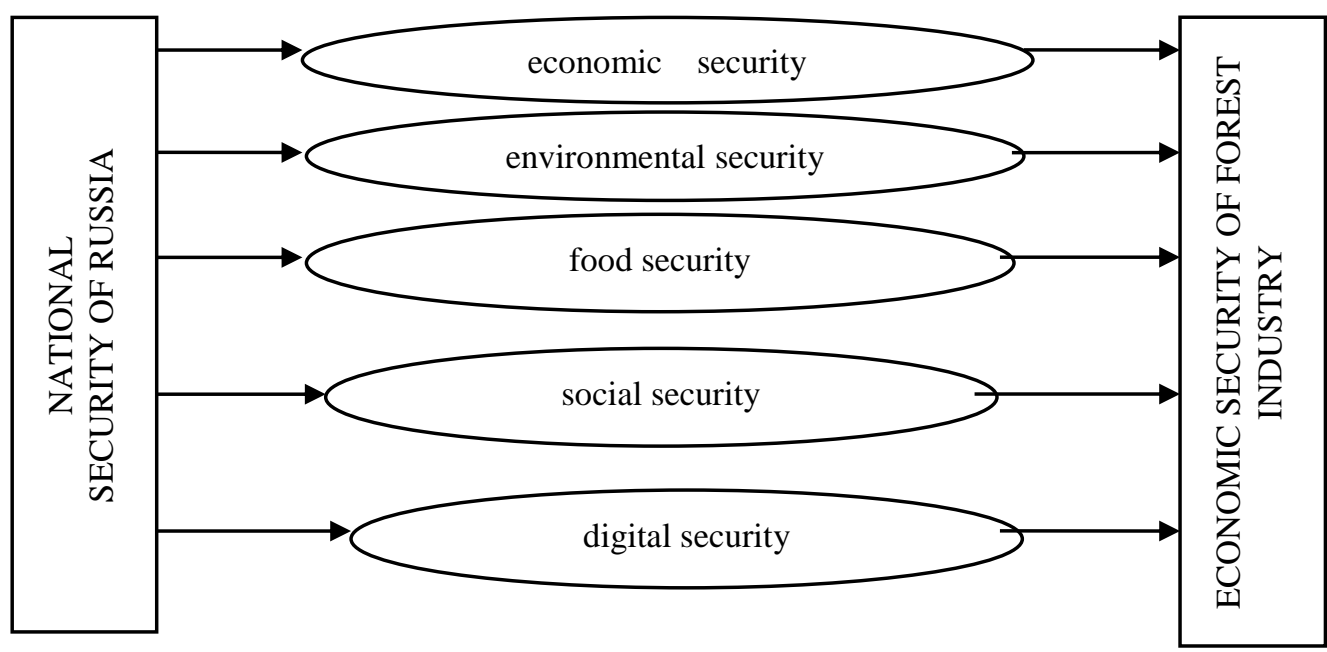


Anthropogenic impact on the natural landscapes of the vast forest, steppe and foreststeppe zones of the European South and North-West of our country, the Far East and sea-bird had a significant impact on the breed-quality composition of trees growing now in these areas. In this regard, modern Russian and foreign experts have proved that cultural afforestation is not only environmentally appropriate, but also economically effective (Petrov, 2017).

The relationship between environmental safety and economic security of the timber industry is obvious, because the forest for humans is a source of a wide range of environmental services, including: smoothing the sharp fluctuations of weather, reducing wind speed, maintaining fertile soil in the fields, reducing noise, the likelihood of drought and floods.

As proof of the relationship of the forest industry with food security, we note that only in 2012 our country exported the highest 10 thousand tons of pine nuts, which are collected in the Primorsky territory (about 70\%) and the Tomsk region (about $30 \%$ ). And this is even though, since 2010, activities for the collection and export of pine nuts are subject to licensing. Historically, the geography of centers for processing mushrooms and wild berries is as follows: Siberia, Central and NorthWestern regions, the far East. The degree of use of the leased forest plots for harvesting of wild plants in these Federal districts varies from 39 to $99 \%$, in other districts - from 23 to $29 \%$. In these regions grows more than 100 species of berries, the nutritional value of which are 29 species. Statistics show that more than $90 \%$ of exports of pine nuts accounted for China, $40 \%$ of Siberian mushrooms are distributed in the domestic market, and $20 \%$ are exported to Italy, Germany, the Scandinavian countries, Kazakhstan, China; the remaining $40 \%$ of the harvested mushrooms are consumed by Siberians.

Continuing to establish the relationship of different types of security with the forest industry, we note that, in our opinion, it is difficult to overestimate the role of forest plantations in the conditions of urbanization of the human habitat and the expansion of industrial activity. A well-known fact is that forest plantations favorably affect the microclimatic conditions of cities, supplying them with oxygen and purifying the air from harmful impurities. Social security, taking into account the economic security of the timber industry, in our opinion, is the creation of optimal landscapes, spaces and landscaping, activities to promote a lean attitude to the environment in General, and forests in particular, as well as improving the level of environmental knowledge of vacationers citizens. It should be noted that forest landscapes provide residents of large cities several different in nature and content, but United by one condition, services: recreational, health-treatment, aesthetic.

History shows that the first gardens in Russia were created in XII - Vladimir, Orel, Suzdal. In Moscow, gardens and parks appeared at the turn of the XV-XVI centuries, after which in the XVIII-XIX centuries were created unique in its architecture, territorial location, existing to this day (!) ornamental gardens and parks (Petrodvo- 
rets, Kolomenskoye). Currently, the area of green areas of Russia is almost 13 hectares.

In addition, we cannot imagine modern society without educational, educational and cultural processes. About the forest, as a wise educator of the people, very succinctly told the writer L. M. Leonov in his outstanding novel "Russian forest" (Leonov, 1954) "It would be ungrateful not to name the forest and among the teachers and the few patrons of our people... Forest...taught caution, observation, hard work...We grew up in the forest...the Forest met the Russian man when he was born and accompanied him through all age stages...". Cultural functions of the forest - the development of human communication skills with nature, developed and transmitted from generation to generation, aimed at the development of knowledge and skills in traditional environmental management. Not to mention that the forests carry a cultural phenomenon, to awaken the high feelings in a person thrust to creativity (de revenue architecture, musical instruments, fine arts). Due to the constant expansion of large cities, the alienation of new natural areas for recreation, sports, walking of urban residents is required, which establishes a strong relationship of economic and social security. The allocation of forest areas, the preservation of the highest possible level of biodiversity in the ecological system, contributing to the regulation of the microclimate and intended for the rest of the population, requires the search for additional recreational, natural and economic resources.

Domestic scientists have several points of view on the relationship between economic and digital security of the timber industry complex, for example, the creation of a single information space for complex automation of economic activity processes (Saraykin, 2003) or modern management technologies in the timber industry complex, as well as logistics integration (Khairov, 2017).

Thus, considering the ecological, food, social, information and digital functions of the forest, we consider it appropriate to consider the forest resources of our country as the sphere of national interests of the Russian Federation. Without any doubt, having lost the status of a forest power, Russia and its population will lose not just trees, but an entire ecosystem, which has enormous cultural, historical, religious, food and educational value, which cannot be overestimated.

\section{Results}

In the Russian Federation, the economic security of the forest sector is currently being ensured at a sufficiently high level, cooperation between law enforcement agencies and forest protection is being organized, space monitoring capabilities are significantly expanded and data from drones are being used, which makes it possible to detect a significant number of crimes related to logging in almost all regions of our country (Opalsky, 2013). 
Thus, often law enforcement officers carry out fixing of the fact of illegal logging when the site of the wood is cut down, and commodity assortments are taken out, and places of warehousing of large-size material evidences in territorial divisions of law-enforcement bodies are absent; activity on withdrawal of timber and illegally prepared wood nevertheless is carried out (Figure 2).

Figure 2. Dynamics of volume of the withdrawn timber on preliminary investigated and suspended criminal cases revealed by the staff of divisions on fight against economic crimes and anti-corruption in Russia from 2013 to 2017 (m3)

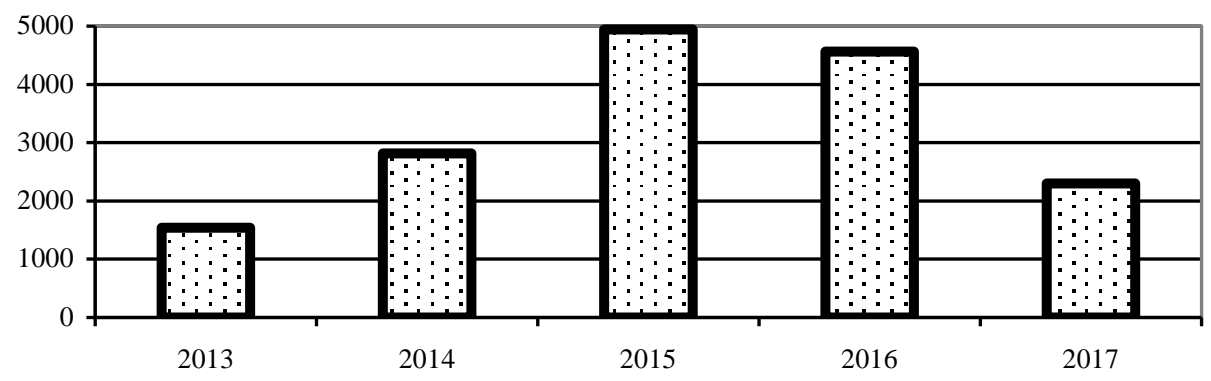

Thus, according to the Main Information and Analytical Center of the Ministry of Internal Affairs of the Russian Federation (MIAC MIA RF) over the past 5 years, employees of units for combating economic crimes and combating corruption seized illegally harvested wood and lumber in volumes from $1500 \mathrm{~m} 3$ to $4945 \mathrm{~m} 3$.

Figure 3. The dynamics of the established amount of damage caused by the completed and suspended criminal cases identified by employees of the units for combating economic crimes and combating corruption in forestry and providing services in the forest industry in Russia from 2013 to 2017 (thousand rubles.)

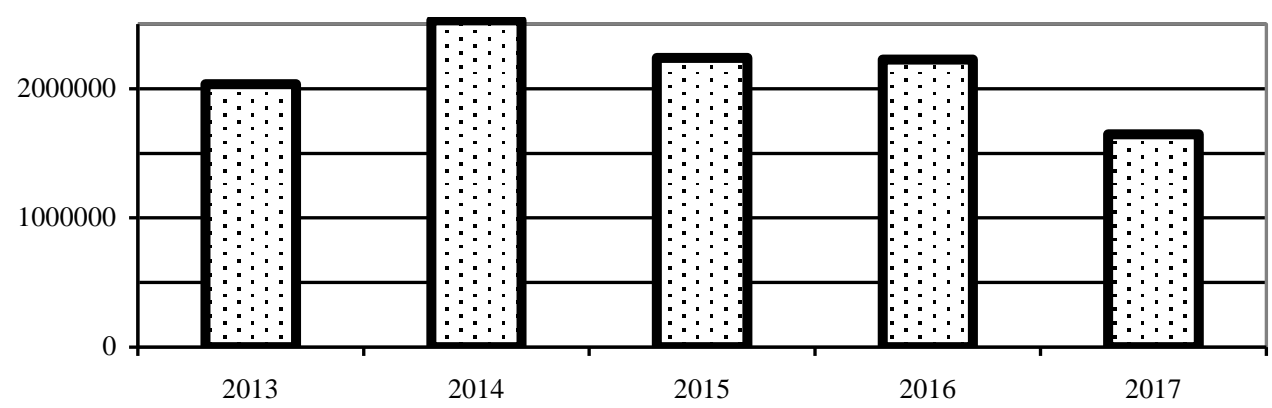

As can be seen from figure 3, in total for the five-year period from 2013 to 2017 in criminal cases sent to the court, the amount of damage amounted to more than 10.6 billion rubles. No doubt the amounts of damage is only a part of the nationwide 
losses from the illegal actions with the wood, not describing the forest sector of economy as an attractive investment.

It should be noted that compensation for damage caused by illegal logging is the most difficult of the tasks assigned to the Executive authorities responsible for the protection and protection of forest resources. Employees of the internal Affairs bodies, carrying out law enforcement activities and ensuring the economic security of the forest industry, within their powers also carry out activities aimed at compensating for damage caused by illegal actions concerning forest resources. It should be noted that the analysis of the reporting and reference information of the departments of internal Affairs of various entities on the subject under consideration for the period from 2010 to 2017 revealed a number of problems that have a negative impact on the indicators of compensation for damage and characteristic of the operational and investigative units of the internal Affairs bodies in the whole country.

First, in the case of non-identification of the perpetrator of a crime or offence, there is no possibility to sue for damages. Secondly, in case of impossibility of transportation of wood and loss of its quality properties (turning into dust).

Third, if it is impossible to establish the Russian Federation as a co-owner of the site where the illegal actions were committed, there is no possibility not only to file a claim for damages, but also in some cases the grounds for initiating a criminal case.

\section{Conclusion}

Based on the analysis of statistical data characterizing the state of economic security of the forest industry in Russia, we consider it appropriate to classify the types of illegal logging of forest plantations:

- "cuts", that is Commission of the cabin in the adjoining sites of forest Fund in the presence of allowing documents on cutting down of plots;

- illegal logging by residents of remote areas near populated areas;

- illegal logging by foreign citizens.

The last type of illegal actions concerning wood, carried out by foreign citizens, is the most common from the border regions, such as the Irkutsk, Kaliningrad and Leningrad regions, the far East and Siberia. As practice shows, foreigners commit crimes, referring to alleged ignorance of Russian legislation and the ban on unauthorized actions in the forest, the rules of withdrawal of plots, the issuance of permits and legal consequences in the form of sanctions for violation of the Criminal code of the Russian Federation.

In the future, violators try to avoid criminal prosecution by misleading representatives of operational and investigative units, as well as local police commissioners 
and investigators. Foreigners report inaccurate information about the name, surname, patronymic, date of birth, place of residence, etc.

Among the most common methods of crimes committed against wood are theft, illegal business, fraud, tax evasion. We will note that the crimes committed concerning wood, have a number of features:

First, this type of criminal activity is characterized by a territorial characteristic. For obvious reasons, where the natural landscape is a desert and semi-desert, the facts of illegal logging are practically not recorded. In those regions of Russia where the considerable territories of forest Fund settle down, continuous growth of such crimes in view of demand for the wood not only from domestic, but also foreign consumers are noted. Among such regions it is necessary to note the Leningrad and Irkutsk regions, the Republic of Karelia and Buryatia, Primorsky and Perm Region. The high level of criminalization of these regions is supported by the constant demand from the neighboring foreign countries - the largest consumers of forest products - Finland, Latvia, Estonia and China.

Second, continuing consideration of the factors contributing to the criminalization of the industry, we note the developed road and rail transport systems, which create additional conditions for the sale of illegally harvested wood.

Third, the reduction in the number of employees of the state forest protection, as well as the lack of employment opportunities of the local population contributes to the organization (Association in criminal groups) and professionalization of forest offenders in the knowledge of legal norms, methods of cutting and transportation of wood "hidden" routes to bypass Federal highways.

Fourth, the remoteness of the settlements from the main places of dislocation and forest law enforcement bodies hamper a systematic survey of forest Rangers and police officers.

Summing up the discussion on the aspects of economic security of the forest industry in Russia, we note that a significant area of forests, not covered by constant monitoring and verification, contributes to:

$\checkmark$ The Commission of the crimes connected with illegal felling of the wood, in full of-evidence for law enforcement officers.

$\checkmark$ The Commission of the crimes connected with illegal felling of the wood, in full of-evidence for law enforcement officers.

$\checkmark$ A long-time gap between the time the crime had been committed and the time it was discovered.

$\checkmark$ Fixing only the fact of illegal cutting down of wood after its export, loss of material evidence, withdrawal of equipment and people, in the absence of witnesses and witnesses of the crime. 
Thus, there is a need for further development of theoretical foundations and methodological recommendations of applied nature to ensure the economic security of the forest industry in Russia, considering the transformation of economic systems and the modernization of the world community.

\section{References:}

Alekseenko, V., Sokolsky, B. 1992. System of Protection of Commercial Objects. Moscow, 195.

Belov, V., Polyansky, A. 1993. Legal Protection of Confidentiality of Trade Secrets. Law and Economics. Moscow.

Bulgakova, M.A. 2013. Organizational and Economic Mechanisms of Ensuring Economic Security of the Timber Industry Complex of the North-Western Region of Russia by the Internal Affairs Bodies. Ph.D. thesis abstract, Moscow.

Gorodetsky, A.E. 1995. Security Issues of the Russian Economy. Economist, 10, 46.

Khairov, B.G. 2017. Logistic Integration in the Timber Industry of Russia. D.Sc. thesis abstract, Moscow.

Kolupaev, V.A. 2002. Formation of the Concept of National Economic Security in Foreign Countries. Belarusian Economy: Analysis, Forecast, Regulation, Economic Bulletin of the Ministry of Economy of the Republic of Belarus, 12, 2-9.

Kornilov, M.Y. 2009. Economic Security of Russia. Textbook, Moscow.

Leonov, L. 1954. The Russian forest. Publishing house of the Central Committee of Komsomol «Young guards», 190.

Lomovtseva, A.V., Trofimova, T.V. 2015. The Essence of Economic Security as an Economic Category. Modern Scientific Research and Innovation, 4p3, http: // web.snauka.ru/ issues/2015/04/47089.

Maslow, A. 2014. Motivation and Personality. Saint Petersburg, Publishing House «Peter».

Maximov, S.V. 2018. Development of Competition - a Priority Direction of the State Policy of Russia. Russian Competition Law and Economics, 1(13), 4-5.

Neu, C.R., Wolf, C. 1994. The Economic Dimensions of National Security. RAND, 11.

Opalsky, A.P., Potrubach, N.N. 2013. Organizational, Economic and Legal Mechanisms for the Implementation of National Interests in the Forest Sector. Monograph, Moscow, JSC «Institute of Microeconomics», 308.

Petrov, A.P. 2016. Materials to the report «Economic Relations in Forestry: from the Past to the Future», http://cepl.rssi.ru/wpcontent/uploads/2016/02/\%D0\%9D\%D0\%94_2016_0225_\%D0 $\% 9 F \%$ D0\%B5\%D1\%82\%D1\%80\%D0\%BE\%D0\%B2_\%D0\%9F\%D1\%83\%D1\%88 $\% \mathrm{D} 0 \% \mathrm{BA} \% \mathrm{D} 0 \% \mathrm{~B} 8 \% \mathrm{D} 0 \% \mathrm{BD} \% \mathrm{D} 0 \% \mathrm{BE} . \mathrm{pdf}$.

Saraykin, V.G. 2003. Creation of a Single Information Space for Complex Automation of Processes of Economic Activity in the Timber Industry. D.Sc. thesis, Voronezh.

Senchagov, V.K. 1995. On the Essence and Basics of the Strategy of Economic Security of Russia. Economic Issues, 1, 98-99. 